\title{
足趾踵荷重位での立位姿勢保持課題が 姿勢制御機能に与える影響
}

\author{
Influence of Toe-heel Loading on Postural Control When Standing
}

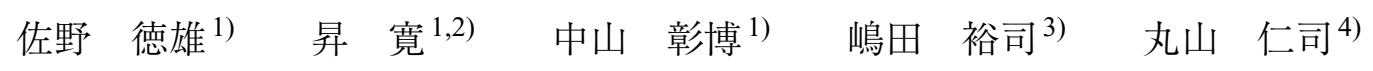

Norio SANO, RPT, MS ${ }^{1)}$, Hiroshi NOBORI, RPT, PhD $^{1,2)}$, AKIHIRo NAKAYAMA, RPT, MS ${ }^{1)}$, YUJi SHIMADA, RPT, MS ${ }^{3)}$, Hitoshi MARUYAMA, RPT, $\mathrm{PhD}^{4)}$

${ }^{1)}$ Department of Physical Therapy, Faculty of Medical Sciences, Teikyo University of Science: 2525 Yatsusawa, Uenohara-shi, Yamanashi 409-0193, Japan TEL: +81 554-63-4411E-mail: n-sano@ntu.ac.jp

2) Department of Judo Therapy, Faculty of Medical Sciences, Teikyo University of Science

${ }^{3)}$ Department of Rehabilitation, Seibo Hospital

4) Vice Dean of Graduate School of International University of Health and Welfare

Rigakuryoho Kagaku 33(3): 379-383, 2018. Submitted Nov. 9, 2017. Accepted Dec. 21, 2017.

ABSTRACT: [Purpose] To clarify the influence of toe-heel loading on postural control when standing. [Subjects and Methods] Fifty-four healthy adults were divided into intervention (27) and control (27) groups. The former performed the motor task of standing with toe-heel loading 3 times weekly for 3 consecutive weeks. [Results] Interactions were observed after intervention in the effective area, center-of-pressure (CoP) displacement in the y-coordinate plane, postural stability index value, $\mathrm{CoP}$ displacement in the y-coordinate plane when the center of gravity was displaced forward, the toe grip strength of the non-dominant leg, and functional reach. [Conclusion] Standing with toe-heel loading may improve postural control in the anterior direction.

Key words: standing with toe-heel loading, postural control, task-specificity

要旨：〔目的〕足趾踵荷重位での立位姿勢保持課題が, 姿勢制御機能に与える影響を明らかにすることを目的とした。 〔対象と方法〕対象は健常成人 54 名とし, 介入群とコントロール群に 27 名ずつ振り分けた. 運動課題は足趾踵荷重 位での立位姿勢保持とし, 週 3 回の介入を 3 週間継続して実施した。〔結果〕実効值面積, 動摇中心偏位 y 座標, 姿 勢安定度評価指標, 前方重心偏位時の動摇中心偏位 $\mathrm{y}$ 座標, 非利き足の足趾把持筋力, Functional reach test の測定結 果に介入前後で交互作用が認められた。〔結語〕足趾踵荷重位での立位姿勢保持は, 前方への姿勢制御機能を向上さ せることが示唆された.

キ一ワード：足趾踵荷重立位, 姿勢制御機能, 課題特異性

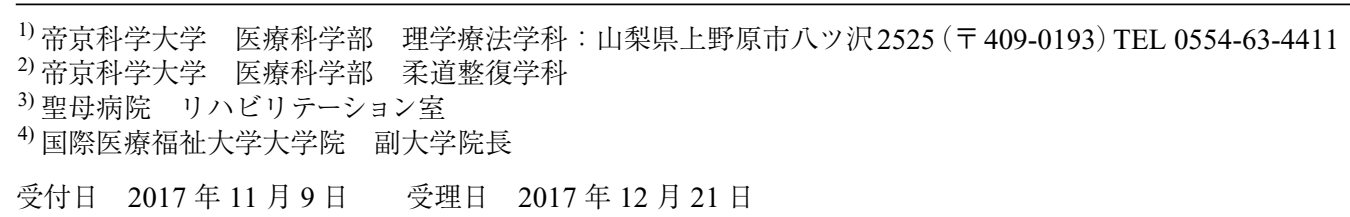




\section{I.はじめに}

二足歩行を行うヒトにとって足底は唯一の接地面であ り，足趾が姿勢制御に果たす役割は大きい。そのため, 足趾機能と立位バランスの関係はこれまで数多く報告さ れてきた ${ }^{1-5)}$.

足趾機能卜レーニングには，タオルギャザーなどが一 般的に行われているが，近年では荷重下で様々な姿勢制 御課題を実施することが，足趾機能改善により効果的で あるとの報告もされている6)。昇ら 7) は，荷重下での足 趾機能トレーニングを目的とした，足指・踵荷重起立台 （実用新案登録第 3201544 号，竹井機器工業社製）を考 案, 作製した。この起立台は, 足趾と踵部のみが接地し た立位姿勢（以下，足趾踵荷重立位）を取らせることで 足趾屈曲筋群の等尺性収縮を誘発させ，足趾把持筋力や バランス機能の向上に効果があるとされる運動機器であ る（図 1）。足指・踵荷重起立台は, 基盤, 足指荷重台, 踵荷重台の 3 部品からなり，基盤は横 $360 \mathrm{~mm}$ ，縦 330 $\mathrm{mm}$, 厚さ $10 \mathrm{~mm}$, 足指荷重台と踵荷重台は横 $135 \mathrm{~mm}$, 縦 $30 \mathrm{~mm}$, 厚さ $15 \mathrm{~mm}$, 足指荷重台と踵荷重台の位置 は磁石により固定，調整することが可能である.

先行研究によると, 足指・踵荷重起立台使用時の活動 電位を表面筋電図で測定した結果，下肢筋群の活動電位 が有意に増加したとされており ${ }^{8)}$, 短趾屈筋の活動電位 は最大随意等尺性収縮（maximal voluntary contraction： 以下, MVC) の約 $80 \%$, 短母趾屈筋の活動電位は MVC の約 $100 \%$ になると報告されている ${ }^{9)}$. また，足 趾踵荷重立位の即時効果は, 10 秒間の施行で足趾把持 筋力が有意に増強したが，30 秒以上の実施では有意な 差は認められなかったとされている10)。このように, 足趾踵荷重立位の運動負荷や, 即時効果については明ら かにされているものの，足趾踵荷重立位が姿勢制御機能 に与える影響や，その継続的な介入効果については未だ 十分な検証がなされていない.

姿勢制御機能の評価には，従来 Functional reach test （以下，FRT）や片脚立位時間などが用いられてきたが, 近年，重心動摇計を用いた動的姿勢制御機能の評価指標 として, 姿勢安定度評価指標（index of postural

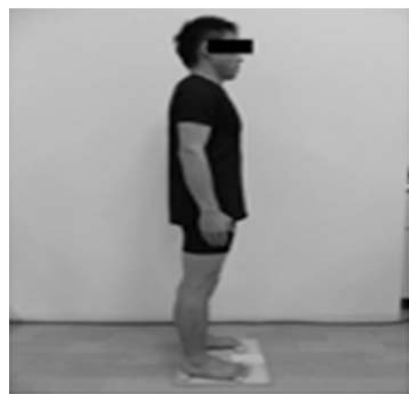

図1 足指・踵荷重起立台実施姿勢
stability：以下，IPS）11)が注目されている. IPS は，天 井効果を示すことなく測定が可能であり，Berg balance scale との相関関係も報告されている12)。 その基本的な 考え方としては，一定の支持基底面内で随意的に重心移 動できる範囲を安定性限界と定義し, 安定性限界が大き く重心動摇が小さいほど姿勢保持の安定性は高くなると いうものであり，安定性限界面積と重心動摇面積の比の 対数值から IPS を算出する。また, 修正 IPS (modified index of postural stability：以下, MIPS）は閉眼，軟面 上条件下で測定する IPS であり，動的バランス能力にお ける深部感覚の影響を検討できる評価指標である ${ }^{12)}$. IPS と MIPS の算出方法は，安定性限界面積を前後左右 の重心移動位置における平均重心位置の距離を乗じた矩 形面積とし，重心動摇面積を中央と前後左右に重心移動 した位置における 10 秒間の矩形重心同様面積の平均值 として, $\log [$ (安定性限界面積 +重心動摇面積 $)$ ／重心 動摇面積]の式を用いるとされている。

本研究では, 足趾踵荷重立位を継続して実施すること による，姿勢制御機能への影響を検証するため，運動課 題前後の姿勢制御機能を IPS や MIPS などを用いて比較 検討することとした

\section{II. 対象と方法}

\section{1. 対象}

対象は，整形外科的疾患がなく，足趾や足関節に関節 可動域制限のない健常成人 54 名とし, 介入群 27 名（男 性 18 名, 女性 9 名), コントロール群 27 名（男性 20 名 女性 7 名）の 2 群に振り分けた。介入群の属性は，年齢 $21.1 \pm 0.4$ 歳，身長 $166.2 \pm 8.9 \mathrm{~cm}$, 体重 $59.8 \pm 9.7$ $\mathrm{kg}$, 足長 $23.3 \pm 2.1 \mathrm{~cm}$ (平均值 \pm 標準偏差) であった. コントロール群の属性は年齢 $20.6 \pm 1.5$ 歳, 身長 $167.4 \pm 7.6 \mathrm{~cm}$, 体重 $62.2 \pm 12.2 \mathrm{~kg}$, 足長 $24.7 \pm 1.5$ $\mathrm{cm}$ であった。対象者には口頭と書面にて，研究の趣旨 と内容, 得られたデー夕は研究目的以外で使用しないこ と，個人情報の漏洩に注意することを説明し，研究参加 の同意を得た。なお，本研究は帝京科学大学倫理審査委 員会の承認を得て実施した（承認番号第 16053 号).

2. 方法

実施手順は，最初に介入群とコントロール群の測定を した後， 3 週間の介入期間を設けた。 その後，再度両群 の測定を行い, 結果の比較検討を行った.

介入群の運動課題は，足指・踵荷重起立台を使用した， 足趾踵荷重立位とした。足指荷重台には中足趾節関節よ り末梢部，踵荷重台には踵骨の中央部を置くこととし た．視線は前方に向けさせ，「足の指と踵以外が基盤に 接地しないように直立姿勢を保持して下さい」，「足の指 と踵部には同じくらい体重が乗るようにして下さい」と 
指示し, 足趾踵荷重立位を保持させた。運動課題の実施 時間は, 運動強度から 10 秒間 2 回の施行を 1 セットとし, 1 日 2 セット実施した 9,10,13)。頻度と期間は, 筋力増強 が望めるとされる週 3 回, 3 週間とした ${ }^{14)}$.

測定項目は, 静的姿勢制御機能として, 開眼立位での 総軌跡長, 単位面積軌跡長, 実効值面積, 動摇中心偏位 ( $\mathrm{x}, \mathrm{y}$ 座標). 動的姿勢制御機能として, IPS, MIPS, 前後への最大重心偏位時の動摇中心偏位（y座標）とし た。 パフォーマンス項目として，FRT，利き足と非利き 足の足趾把持筋力とした。重心動摇計は, Active Balancer EAB-100 (酒井医療社製) を使用し, サンプ リング周波数は $20 \mathrm{~Hz}$ とした。また，軟面マットは AIREX ${ }^{\circledR}$ Balance-pad（AIREX 社製）を使用した。

静的姿勢制御機能の測定は，両足底内側を $10 \mathrm{~cm}$ 離し， 足部は内外旋中間位にした自然立位を開始姿勢とした。 視線は $2 \mathrm{~m}$ 先にある目標物を注視するよう指示した。

IPS とMIPS は，開眼して裸足，足底内側を平行に 10 $\mathrm{cm}$ 離した軽度開脚立位を開始姿勢とし，初期の大きな 動摇がおさまった時点から 10 秒間の重心動摇を測定し た，その後，対象者に「直立姿勢を変えない上うに体を 傾けて下さい」と指示し, 前方・後方・右側・左側の順 に重心移動した位置に招ける 10 秒間の重心動摇を測定 した。測定終了後, 検查台に軟面マットをセットし, IPS と同様に重心動摇を測定した.

前後への最大重心偏位時の動摇中心偏位（y 座標）は, 両足底内側を $10 \mathrm{~cm}$ 離し，足部は内外旋中間位にした 自然立位を開始姿勢とした，対象者に直立姿勢を保持し たまま最大限前方，あるいは後方に重心を偏位させた後， 初期の動摇が拐さまった時点から 10 秒間の重心移動を 測定した

FRT は, 足幅を肩幅程度に開いた立位で，肩関節屈曲 $90^{\circ}$ 位, 肘関節伸展位, 前腕回内位, 手関節中間位を開 始肢位とし，第三指尖先端の位置を開始位置とした。前 方へリーチする際は，視線は指先を見たまま上肢を肩の 高さから上下させず，足底を床面から浮かさないように 指示した，測定後，開始肢位に戻らせて測定終了とした。

足趾把持筋力の測定には, 足指筋力測定器 II (竹井機 器工業社製）を使用した。両下肢は肩幅に開脚させ，股 関節膝関節屈曲 $90^{\circ}$, 足関節を底背屈 $0^{\circ}$, 両上肢は大腿 中央部に置いた状態を開始姿勢とし, 足底全面が機器に 接地するよう調節した。測定器の設定は, 測定用のバー が母趾の趾節間関節と示趾の遠位趾節間関節にかかるよ うに設定した. 左右 3 回ずつ測定し，それぞれの最大值 を代表值とした。

統計解析は, 各測定項目について介入前後と介入の有 無を 2 要因とした二元配置分散分析を行った。交互作用 を認めた場合には，対応のある $\mathrm{t}$ 検定を用いて検討した。 なお統計処理は SPSS Statistics21 を使用し, 有意水準は $5 \%$ とした。

\section{III. 結 果}

介入前後と介入の有無による測定結果を表 1 に示す. 二元配置分散分析の結果, 実効值面積, 動摇中心偏位（y 座標）, IPS，前方最大重心偏位時の動摇中心偏位（y 座 標），非利き足の足趾把持筋力，FRTに打いて有意な交 互作用が認められた。実効值面積，IPS，FRTでは介入 前後で主効果が認められた。実効值面積, 動摇中心偏位 （y 座標）では介入の有無による主効果が認められた.

\section{IV. 考 察}

まず，静止立位での重心動摇について考察する。総軌 跡長, 単位面積軌跡長, 実効值面積では, 実効值面積の み交互作用が認められ, 両群ともに数值が増加, つまり 重心動摇が大きくなった．静止立位時の動摇中心偏位は, $\mathrm{x}$ 座標で有意な差は認めず, $\mathrm{y}$ 座標で介入群の足圧中心 が前方に偏位した，先行研究によると，若年者では足趾 把持筋力と静的バランスは負の相関関係が認められ ${ }^{15)}$, 高齢者に执いては足趾機能トレーニングによって静的バ ランス機能が向上すると報告されている16). しかし, 本研究では実効值面積の值から, 重心動摇が大きくなり 先行研究とは異なる結果が示された。この要因として, 動摇中心偏位の変化が関与していると考える. 前後方向 を示す $\mathrm{y}$ 座標は, 介入群の值が介入前と比較して増加し て抢り，静止立位状態での足圧中心が前方に偏位したこ とを意味する，本研究では，その原因を特定することは 困難であるが，これまでとは異なる重心位置での姿勢制 御反応を引き出した結果, 重心動摇が大きくなったので はないかと考えた．また，対象者が足部抢よび足趾の関 節可動域制限や整形外科的疾患を持たない健常成人で あったことも要因として考えられる．若年者においても 足趾機能トレーニングによって足趾機能が改善するとさ れているが，その多くは動的姿勢制御機能やパフォーマ ンスの改善である 17-20)。健常成人に抒いては，そもそ も静止時立位時の重心動摇は少ないため, 介入効果が認 められなかったと考えた.

次に，動的姿勢制御について考察する，前後へ重心を 最大に偏位させた時の動摇中心偏位は，前方向でのみ交 互作用を認めた。動摇中心偏位の $\mathrm{y}$ 座標の増加は, 前方 への重心移動距離の向上を示している。これは足趾踵荷 重立位の運動課題特性と, 足底の固有感覚が賦活された ことによる姿勢制御機能の向上を考えた。村田ら ${ }^{21)} は$, 短期間での足趾トレーニングにより足底の固有感覚の賦 活が望めると考察しており, 島田ら ${ }^{22)}$ は, 平衡機能卜 レーニングは, 練習内容に対応した課題特異性があると 報告をしている。 また，辻野ら 23) は，前方に偏位した 重心を保持するためには，足関節底屈筋力だけではなく， 前足部や足趾の屈曲方向への圧力も重要であると報告し 
表 1 介入前後と介入の有無の測定結果

\begin{tabular}{|c|c|c|c|}
\hline & & 介入前 & 介入後 \\
\hline \multirow[t]{2}{*}{ 総軌跡長（mm） } & 介入群 & $188.2 \pm 23.9$ & $200.6 \pm 25.6$ \\
\hline & コントロール群 & $187.5 \pm 24.2$ & $214.5 \pm 48.8$ \\
\hline \multirow[t]{2}{*}{ 単位面積軌跡長（mm） } & 介入群 & $6.3 \pm 3.6$ & $5.1 \pm 2.0$ \\
\hline & コントロール群 & $5.5 \pm 2.2$ & $4.6 \pm 2.4$ \\
\hline \multirow[t]{2}{*}{ 実効值面積 $\left(\mathrm{mm}^{2}\right) *$} & 介入群 & $50.4 \pm 29.8^{\# \dagger}$ & $56.6 \pm 39.0^{\# \dagger}$ \\
\hline & コントロール群 & $49.7 \pm 27.6$ & $87.8 \pm 105.7$ \\
\hline \multirow[t]{2}{*}{ 動摇中心偏倚 x 座標（mm） } & 介入群 & $4.4 \pm 6.6$ & $2.3 \pm 5.4$ \\
\hline & コントロール群 & $1.8 \pm 7.0$ & $2.1 \pm 6.0$ \\
\hline \multirow[t]{2}{*}{ 動摇中心偏倚 $\mathrm{y}$ 座標 $(\mathrm{mm}) *$} & 介入群 & $-28.0 \pm 19.4^{\dagger}$ & $-20.7 \pm 20.2^{\dagger}$ \\
\hline & コントロール群 & $-34.1 \pm 16.2$ & $-36.5 \pm 17.2$ \\
\hline \multirow[t]{2}{*}{ IPS* } & 介入群 & $1.9 \pm 0.2^{\#}$ & $1.8 \pm 0.2^{\#}$ \\
\hline & コントロール群 & $1.9 \pm 0.2$ & $1.7 \pm 0.3$ \\
\hline \multirow[t]{2}{*}{ MIPS } & 介入群 & $0.5 \pm 0.2$ & $0.5 \pm 0.2$ \\
\hline & コントロール群 & $0.4 \pm 0.2$ & $0.4 \pm 0.2$ \\
\hline \multirow[t]{2}{*}{ 前方重心偏倚時の動摇中心偏倚 $\mathrm{y}$ 座標 $(\mathrm{mm}) *$} & 介入群 & $36.1 \pm 17.9$ & $43.6 \pm 17.6$ \\
\hline & コントロール群 & $36.7 \pm 18.2$ & $35.0 \pm 18.8$ \\
\hline \multirow[t]{2}{*}{ 後方重心偏倚時の動摇中心偏倚 y 座標（mm） } & 介入群 & $-78.7 \pm 20.6$ & $-80.4 \pm 16.6$ \\
\hline & コントロール群 & $-78.6 \pm 10.4$ & $-78.5 \pm 13.1$ \\
\hline \multirow[t]{2}{*}{ 利き足足趾把持筋力（kg） } & 介入群 & $19.1 \pm 8.0$ & $19.5 \pm 8.8$ \\
\hline & コントロール群 & $16.8 \pm 5.5$ & $18.6 \pm 3.9$ \\
\hline \multirow[t]{2}{*}{ 非利き足足趾把持筋力 $(\mathrm{kg}) *$} & 介入群 & $18.2 \pm 8.0$ & $17.5 \pm 8.1$ \\
\hline & コントロール群 & $15.8 \pm 5.2$ & $17.6 \pm 5.3$ \\
\hline \multirow[t]{2}{*}{ FRT $(\mathrm{cm}) *$} & 介入群 & $16.7 \pm 3.0^{\#}$ & $20.6 \pm 4.4^{\#}$ \\
\hline & コントロール群 & $17.5 \pm 5.1$ & $18.4 \pm 4.2$ \\
\hline
\end{tabular}

平均值 \pm 標準偏差, $*$ : 交互作用 $(\mathrm{p}<0.05)$, \# : 介入前後で有意差あり $(\mathrm{p}<0.05)$, † : 介入群とコント ロール群で有意差あり $(\mathrm{p}<0.05)$.

ている，足趾踵荷重立位は，立位姿勢で足趾屈曲筋群の 等尺性収縮を促す運動課題であり，重心の前方移動を制 御する機能と同様の収縮動態であると考えられる。つま り, 足趾踵荷重立位は足趾屈曲筋を賦活し, 足底末梢部 を有効支持基底面として姿勢制御に動員することが可能 となり，前方制御機能を特異的に向上させた可能性が考 えられる。また, FRTも前方重心偏位時の動摇中心偏 位が向上したことと同様に, 前方への重心移動が円滑に 行えるようになったことで向上を認めたものと考えた. 一方, IPS と MIPS では, IPS でのみ交互作用を認めたが, 介入後に低下する結果となった，IPS は，前後左右方向 での総合的な動的姿勢制御能を評価する動的姿勢制御機 能の評価指標である ${ }^{11)}$ ，足趾踵荷重立位によって前方 への重心移動距離の向上を認めたが, 重心動摇は大きく なった。これらのことから, 重心移動距離が増加したこ とと相反的に重心動摇は大きくなり，総合的に IPS は低 下したものと考えた

最後に足趾把持筋力について考察する. 利き足の足趾 把持筋力には有意差が認められず，足趾踵荷重立位に よって即時的に足趾把持筋力が増加するとした先行研 究10)とは異なる結果を示した。そその要因として, 測定
時期の違いと課題特異性が考えられる。本研究では最後 の運動課題から数日後に最終測定を行っている. 20 日 間未満のトレーニングの場合, 筋肥大は起こらず, 神経 的要因に起因する筋力増強が起こるとされ, 筋収縮活動 に参加する運動単位の増加や, 活動の夕イミングの一致 によりもたらされる 14)。本研究においては, 運動課題 から数日経過した後に測定したため, 同期化が円滑に行 われず，有意な向上が認められなかったと考えた。また， 足趾踵荷重立位は足趾が屈曲伸展中間位のまま等尺性収 縮を促す運動課題であるが, 足趾把持筋力は足趾で握り 込む運動課題である. 筋力増強トレーニングは, 目的動 作と同様のトレーニングを実施することが効果的とされ ており 24), 本研究においては運動様式の違いから, 筋 力増強効果が低かったことが考えられる。コントロール 群の非利き足の足趾把持筋力が増加した要因としては, 介入前の筋力が低かったことが考えられる。初期と最終 で足趾把持筋力計での測定を行うことにより，足趾把持 の運動様式が学習され, 足趾把持筋力が増強したと考 える.

本研究の限界として, 既存の足趾機能トレーニングと の効果に関する比較が行えていないことが挙げられる. 
今後は，足趾踵荷重立位の特性を既存のトレーニングと 比較することで明らかにする必要があると考える。また， 村田ら 25) は, 高齢者の足趾把持筋力は若年者と比較し 低下するとしている，そのため，今後は高齢者に対する 効果検証を行う必要があると考えた。

本研究は, 足趾踵荷重立位課題の介入効果を姿勢制御 機能から検証した，その結果，足趾踵荷重立位は，静止 立位での足圧中心を前方へ偏位させ，前方への重心移動 距離を増加させる一方, 相反的に重心動摇が大きくなる 運動課題であることが明らかとなった。 また，足趾把持 筋力の増強を認めないことから, 立位での前方重心制御 能を向上させる特異的な運動課題である可能性が示唆さ れた。

利益相反 本研究において開示すべき利益相反はない.

\section{引用文献}

1) 木藤伸宏, 土井秀俊, 三輪 恵・他：高齢者の易転倒性を 予測する因子の抽出と，その予防の為の訓練法の開発。健 康医科学研究助成論文集, $2000,15: 25-36$.

2) 木藤伸宏, 土井秀俊, 三輪 恵 - 他 : 高齢者の転倒予防と しての足趾トレーニングの効果. 理学療法科学, 2001, 28: 313-319.

3) 村田 伸, 津田 彰, 稲谷ふみ枝 - 他 : 在宅障害高齢者 の転倒に影響を及ぼす身体及び認知的要因. 理学療法学, 2005, 32: 88-95.

4) 村田 伸, 津田 彰: 在宅障害高齢者の身体機能・認知機 能と転倒発生要因に関する前向き研究. 理学療法学, 2006, 33: $97-104$.

5) 村田 伸, 津田 彰：在宅障害後期高齢者に対する足把持 カトレーニングの転倒予防効果. 健康支援, 2005, 7: 11-18.

6) Kelly LA, Kuitunen S, Racinais S, et al.: Recruitment of the plantar intrinsic foot muscles with increasing postural demand. Clin Biomech (Bristol, Avon), 2012, 27: 46-51.

7) 昇 寛, 石川孝司, 松本泰章：足指・踵起立盤の考案と作 製. 日本スポーツリハビリテーション学会誌，2015, 4: 35-37.

8) 嶋田裕司, 昇 寞, 冨田圭佑 - 他: 足指 - 踵荷重起立の下 肢7筋への影響—活動筋電位による観察—. 理学療法科学, 2017, 32: 297-300.

9) 佐野德雄, 中里愛未, 柳川大吾・他 : 足指把持筋力トレー ニング時の短指屈筋と短母指屈筋の筋活動量. 日本スポー ツリハビリテーション学会誌, 2017, 6: 37-42.
10) 佐野德雄, 昇 寛, 中山彰博 - 他 : 足指踵荷重での立位保 持時間が足指把持筋力に与える影響. 理学療法科学, 2017, 32: 377-380.

11) 望月 久, 峯島孝雄: 重心動摇計を用いた姿勢安定度評価 指標の信頼性㧍よび妥当性. 理学療法学, 2000, 27: 199203.

12) 鈴木康裕, 中田由夫, 加藤秀典 ·他 : 重心動摇計を用いた 動的バランス能力と年齢の関係. 体力科学, 2015, 64: 419425.

13) 市橋則明, 松原貴子, 神先秀人 - 他: 運動療法学 障害別ア プローチの理論と実際, 第2版。市橋則明(編), 文光堂, 東京, 2016, p225.

14) 中道哲朗, 渡邊裕文:筋力低下に対するアプローチ. 関西理学, 2014, 14: 11-15.

15) 佐々木諒平: 足趾機能がバランス能力に与える影響について. 理学療法, 2010, 17: 14-17.

16) 小林隆司, 細田昌孝, 峯松 亮·他: 高齢者の足趾把握 訓練が静的重心動摇に及ぼす影響. 日災医会誌，1999, 47: 633-636.

17) 藤高紘平, 藤竹俊輔, 来田晃幸: 大学サッカー選手の足部 足関節損傷に対する足部アーチ保持筋力トレーニングの効果. 理学療法科学, 2012, 27: 263-267.

18）相馬正之, 五十嵐健文, 工藤 涉 ・他 : 足指把持力トレー ニングがFunctional Reach Test や最大 1 歩幅, 歩行能力に 与える影響について. ヘルスプロモーション理学療法研究, 2012, 2: 59-63.

19) 竹井和人, 村田 伸, 甲斐義浩・他：足把持力トレーニング の効果. 理学療法科学, 2011, 26: 79-81.

20) 金子 諒, 藤澤真平, 佐々木誠：足指把持筋力トレーニン グが最大速度歩行時の床反力に及ほす影響. 理学療法科学, 2009, 24: 411-416.

21) 村田 伸, 忽那龍雄：在宅障害高齢者に対する転倒予防対 策一足把持力トレーニングー. 日本在宅ケア学会誌, 2004, 7: 67-74.

22) 島田裕之, 内山 靖：高齢者に対する 3 力月間の異なる運 動が静的・動的姿勢バランス機能に及ぼす影響. 理学療法学, 2001, 28: 38-46.

23) 辻野綾子, 田中則子：足趾圧迫力と前方リーチ動作時の足 圧中心位置の関係. 理学療法科学, 2007, 22: 245-248.

24) 市橋則明：臨床理学療法領域におけるコア・パラダイム— 筋力トレーニングに扔けるパラダイムシフトー. 理学療法学, 2015, 42: 695-696.

25) 村田 伸, 甲斐義浩, 田中真一・他：健常成人と高齢者に おける足把持機能の比較. 理学療法科学, 2007, 22: 341344 . 